\title{
THE POLITICS AND AESTHETICS OF STORYTELLING IN DIANA ABU-JABER'S CRESCENT: A STRATEGIC IMPLEMENTATION OF AN OLD FOLKLORIC ARAB TRADITION
}

\author{
Ishak Berrebbah \\ Coventry University, UK
}

\begin{abstract}
This paper discusses the politics and multi-functionality of storytelling in Diana Abu-Jaber's novel Crescent (2003). I argue that the strategic use of storytelling places Crescent as a complex hybrid text that projects the nature, and development, of Arab American literature in the contemporary era. In addition to having the practice of storytelling as an apparatus to project identity in Crescent, Abu-Jaber reappropriates its empowered status in Arab culture as well as politicizes its image in the mind of her readers. Besides employing critical and analytical approaches to the novel, this paper relies on arguments and perspectives of prominent postcolonial and literary critics and theorists such as Edward Said, Suzanne Keen, Walter Benjamin, and Somaya Sami Sabry, to name a few.
\end{abstract}

Keywords: Arab American, orality, storytelling, identity, Diana Abu-Jaber, hybrid text

\author{
Article history: \\ Received: 19 April 2020; \\ Reviewed: 29 April 2020; \\ Revised: 8 May 2020 \\ Accepted: 10 May 2020; \\ Published: 30 June 2020
}

\section{Copyright (C) 2020 Ishak Berrebbah}

This open access article is published and distributed under a CC BY-NC 4.0 International License which permits non-commercial use, distribution, and reproduction in any medium, provided the original author and source are credited. Permissions beyond the scope of this license may be available at berrebbi@uni.coventry.ac.uk. If you want to use the work commercially, you must first get the authors' permission.

Citation: Berrebbah, I. (2020). The Politics and Aesthetics of Storytelling in Diana Abu-Jaber's Crescent: A Strategic Implementation of an Old Folkloric Arab Tradition. English Studies at NBU, 6(1), 127-144.

https://doi.org/10.33919/esnbu.20.1.6

\begin{abstract}
Ishak Berrebbah is a Doctoral researcher and a postgraduate teaching assistant at Coventry University, UK. His research project investigates the poetics and politics of identity in Arab American fiction in the context of post-9/11. He was awarded a fully funded scholarship by the Algerian government in 2016 to pursue $\mathrm{PhD}$ degree in the United Kingdom. He has published in the field of English Literature and presented many papers at international conferences in different countries, but mainly in the UK. His research interests intersect Diaspora studies, Postcolonial literature, and Arab Literature in English.
\end{abstract}


Storytelling suggests telling existent stories to the audience while the audience is involved and whenever the audience is involved, there are multiple interpretations involved as well.

(Tabackovà, 2015, p. 116)

The art of storytelling is one of the human race's oldest cultural traditions. In its simple definition, storytelling is "the vivid description of ideas, beliefs, personal experiences, and life-lessons through stories or narratives that evoke powerful emotions or insights" (Serrat, 2008, p. 1). This art of orality has a significant place in Arab culture. In fact, Arab culture per se "is an originally oral culture in which the spoken word occupies a central position" (Herzog, 2012, p. 627). Tarik Sabry, for instance, explains that "Arab oral popular cultures (turath sha'bi), including storytelling, poetry and other creative forms [...] constitute an important element of the cultural heritage that made it into the written word" (2010, p. 57). Indeed, transforming such cultural heritage into the written word, as Magali Cornier Michael argues, is evident in contemporary Arab American literary creation, especially in modern times (2011).

It should be acknowledged that this paper contributes to Magali Cornier Michael's research article titled "Arabian Nights in America: Hybrid Form and Identity in Diana Abu-Jaber's Crescent" (2011). Michael traces the historical development of One Thousand and One Nights and projects how such a tradition of telling and re-telling stories appears and functions in Abu-Jaber's narratives. She, however, does not acknowledge how such mixed narratives are reflected in the modern era and whether or not they affect readers' engagement with the text. Moreover, her analysis of the novel disregards the role of the storyteller - in this case, the uncle - as a literary device that 'strategically' structures the narratives of Diana Abu-Jaber. As such, this paper provides in-depth analysis of the uncle's storytelling to assess the functionality of orality, as echoed by the uncle, and build on Michael's thesis. The contribution appears in different aspects, such as challenging Walter Benjamin's thought about the ineffectiveness of storytelling technique to trigger reader's engagement with a text and narratives in modern era, projecting the multifunctional role of the storyteller in the novel, constructing a link between storytelling and the life of Arab Americans as lived out in reality - such as Palestinian Americans - and providing other insights that may broaden the horizons of Michael's arguments. 
Storytelling, as Fadda-Conrey points out, is one of the essential tools that shapes the literary outputs of contemporary Arab American authors as well as their affiliations and identity. According to her, "contemporary Arab-American literature is a primary site for envisioning and delineating transnational reconfigurations of citizenship and belonging by virtue of its ability to transform social discourse and to shape subjectivities through the imaginative yet deeply effective tools of narratives and storytelling" (2014, p. 177). Diana Abu-Jaber's novel reflects Fadda-Conrey's statement by perpetuating both the art and style of storytelling in its narratives. It places itself as a medium by which Arab cultural heritage and subjectivities can be discerned and understood. Abu-Jaber herself comments on the tradition of storytelling as an indicator of her original culture - an Arab - as well as a comfort for herself during her growing-up years. Her perspective towards storytelling seems to fall within Irwin and Auster's claim that "stories are fundamental food for the soul" (2013, p.46). Abu-Jaber says:

Storytelling was very important when I grew up. My father and my uncles are all great storytellers, and they regaled us with jokes, fables, and reminiscences about their growing-up years. And that storytelling, along with food, was one of the great pillars of my own cultural education. Thus it was really important to me to try to bring some of that format into Crescent. I wanted the uncle to be telling Sirine, his niece, a story throughout the course of the book. I wanted the story to have the flavor of the oral narrative, and the surprises and the nuances of the spoken voice. (Field, 2006, p. 221)

The novel essentially revolves around the life of two main protagonists: Sirine and Hanif El Eyad (known as Han). The former is a thirty-nine-year-old Iraqi American woman who works as a chef at Um-Nadia's Café, an Arab restaurant located in a Los Angeles Iranian neighbourhood called Tahrangeles. The latter is an Iraqi professor of literature at a nearby university. He chooses exile to flee the dictatorship of Saddam Hussein's regime. The practice of storytelling and its implication in Abu-Jaber's Crescent appears through Sirine's uncle. He is a quintessential storyteller of Arabic folklore and proverbs in the novel. He is an Iraqi immigrant and professor of Near Middle Eastern Studies. He offers a frame for the novel through his episodic stories about the adventurous slave named Abdelrahman Salahadin and his mother Camille. He refers to himself in the novel as an accomplished uncle and storyteller who should be rewarded with "plates of knaffea pastry" (Abu-Jaber, 2003, p. 38). He always appeals to his niece, Sirine, to listen and ponder his storytelling - he claims that "there is an art to listening 
to a story - it requires equal parts silence and receptivity" (Abu-Jaber, 2003, p. 308). For him, the art of storytelling is one of the key aspects of life.

Sirine's uncle ${ }^{1}$ is an important character in the novel as well as a key literary device for the structure of the narratives. Diana Abu-Jaber comments on this particular character as a figure who has a special role in the making up of Crescent: "I think of him so much as 'The Uncle.' And then when I tried to give him a name it felt so false to me, too specific and too personal. I wanted to give him this very archetypal, avuncular presence, because in a way, for a great deal of the book [...] He is the Storyteller" (Field, 2006, pp. 220-221). Interestingly, it might be necessary to draw attention to the description of the uncle as archetypal in Abu-Jaber's statement - a typical personalization of a key character. The uncle can critically be regarded in this way due to characteristics that position him as a wise, educated, experienced, knowledgeable, compassionate, and accomplished person to most characters in the novel such as Han and Sirine. The latter for instance views him as a godfather -Abu-Jaber states that Sirine "sees him strictly as the one who is going to care for her, take care of her, answer her questions, and make her feel safe" (Field, 2006, p. 220). He is an example of the storyteller who "takes what he tells from experience - his own or that reported by others. And he in turn makes it the experience of those who are listening to his tale" (Benjamin, 1968, p. 87).

The uncle's storytelling in Abu-Jaber's novel, moreover, might be seen as a key device that functions to challenge Walter Benjamin's statement that storytelling is witnessing its demise in the modern novel when he claims that "the art of storytelling is coming to an end" (1968, p. 78). This particular art is perpetuated by the uncle in narratives through his constant interventions and eloquence. He is what Derek Matravers calls an 'explicit narrator' who is represented as 'overly punctilious' and responsible for narrating the main story and sustaining the reader's interest by making explicit interventions in the text, especially fictional ones (2014, pp. 119-126). In so doing, Sirine's uncle can be regarded as an "omniscient narrator" (Field, 2006, p. 221) who knows the past as well as the present and the future of both the story he tells and the overall plot of the novel. In this regard, it might also be possible to evoke the notion of 'Author Surrogate': this can be explicated as a literary technique to deliver the

${ }^{1}$ This particular character will appear in this section as both 'the uncle' and 'Sirine's uncle' to avoid distorting repetition. 
author's opinion or message through one of the main characters who is usually the narrator per se. Given that Sirine's uncle is the main narrator in Crescent, Abu-Jaber uses him as a medium to introduce Iraq, and the Middle East in general, to the readers of her novel from her own point of view. This is apparent when Sirine's uncle acts as an informer and teacher of Arab legacies and history within the context of his storytelling, which seems a central method to the remembering of history:

There was once an Arab empire that dominated the world. The glorious Abbasid Empire reigned from the eighth until the thirteenth centuries-five hundred years. And Baghdad was it celestial capital. Now you blink: it is seven or eight centuries later and the world has turned upside down in its usual way. The Abbasid Empire dissolved [...] The Arab Abbasid Empire had enjoyed the same sort of glory as that of the Roman Empire and had achieved the depth of the Greek; it had spanned continents and hemispheres, produced libraries, inventions, and celestial insights-and then it was gone and the Arabs had to go back to being regular people. (Abu-Jaber, 2003, pp. 171-72)

The oral history of the Arab empire as perpetuated by the uncle can critically be seen as an extension of his storytelling, tracking the legacy of Arabs and their historical domination over the world for five hundred years, but also as a method of resisting any deformation/fabrication that Arab history might encounter. In other words, oral history within storytelling is a strategy to both teach and protect history. It should be noted, moreover, that the uncle's account does not glorify the Abbasid Empire - an act of romanticising - but he simply invokes such a piece of information to remind of what he assumes is a disregarded history. The novel, in this way, defines the act of storytelling as an apparatus of voicing neglected histories. Interestingly, the uncle's strategy is, to a great extent, similar to that of Palestinians. The latter, as Nur Masalha explains, deploy the Arab tradition of oral storytelling in the form of al-hakawati (the storyteller) to preserve their historiography, and encounter and resist "Zionist memoricide and toponymicide - the erasure of the material culture of Palestine and Palestinian cultural memory" (2018, p. 27).

In addition, with regard to the term 'Author Surrogate', the uncle also strategically functions as a device by which Abu-Jaber can express her critical socio-historical perspective to discuss the issues that surround the lives of Arabs. This is, by extension, evident in the uncle's storytelling: 
Slavery has been outlawed in most Arab countries for years now. But there are villages in Jordan made up entirely of the descendants of runaway Saudi slaves. Abdelrahman knows he might be free, but he's still an Arab. No one ever wants to be the Arab-it's too old and too tragic and too mysterious and too exasperating and too lonely for anyone but an actual Arab to put up with for very long. Essentially, it's an image problem. Ask anyone, Persians, Turks, even Lebanese and Egyptians-none of them want to be the Arab. (AbuJaber, 2003, p. 54)

This passage denotes the extent to which Arabness can be regarded as a burden and an obstacle to assimilation and being accepted in a foreign culture. Being an Arab, according to the uncle, is an identity that people deny and avoid. It is possible to critically argue that the uncle uses his hero Abdelrahman, within the context of the story, as a prototype of Arabs living in the USA who, on the one hand, struggle to keep their Arab roots, and on the other hand, overcome the negative image of Arabness that has a profound impact on their lives in the wider American society. The experiences of Abdelrahman in his journey from the East to the West in Sirine's uncle's storytelling, therefore, can be regarded as a lesson, or a reference, for Arab American audience and Arabs in general. It tackles how to negotiate Arabness and manage its ramifications in a setting of racism and discrimination, especially in the aftermath of 9/11. Diana AbuJaber in this regard uses the uncle's storytelling as a means to provide a helpful counsel which consequently increases the communicability between her narratives and her readers - particularly Arab Americans and Arabs - on the basis of Abdelrahman's correlating experiences. This confirms, through the art of storytelling, that novels, as Abu-Jaber argues, are "tutorials in how to connect and empathize with others. Novels are one of the very few forms that we have available to really instruct us in the experiences of others" (Field, 2006, p.211).

Abu-Jaber's argument, in this context, challenges Walter Benjamin's view towards the literary functionality of the novel that it poorly replaces the art of storytelling in the modern era. The latter claims that literary forms, such as novels, cannot project the potentiality to invoke shared feelings and collective meaning due to the increasing industrial reproduction that distorts the essence of any original work of art. This consequently features the modern reader as isolated, passively unable to communicate, and unable to show empathy. According to Walter Benjamin, a novel in modern times "neither comes from oral tradition nor goes into it" (1968, p. 77) and that storytelling 
"began quite slowly to recede in the archaic" (1968, p. 78). Abu-Jaber's Crescent, however, seems to prove Benjamin's argument wrong in terms of the idea that a novel, in contemporary times, still intersects with the politics of storytelling and triggers the notions of empathy and communication. Indeed, empathy contributes to the communicability between the reader and Abu-Jaber's narratives, especially characters, in terms of shared emotions or experiences. Suzanne Keen, for instance, observes that "women writers and novelists from around the world endorse the notion of shared human emotions when they overtly call upon their reader's empathy (2007, p. viii). This empathetic engagement with narratives, in analysis of Crescent, might also be regarded as an outcome of the similarity and commonality that occur between Abdelrahman, the Arab character in the uncle's storytelling, and Arab and Arab American readers. This similarity appears in different aspects such as displacement, exile, identity crisis, diasporic conditions, and cultural hybridity, etc. In other words, as Suzanne Keen argues, "readers' empathy for situations depicted in fiction may be enhanced by chance relevance to particular historical, economic, cultural, or social circumstances, either in the moment of first publication or in later times, fortuitously anticipated or prophetically foreseen by the novelist" (2007, p. xii). This means that novelists, such as Abu-Jaber, have the ability to control the extent to which their readers engage with their narratives empathetically. However, it should also be noted that "no one text evokes the same responses in all of its readers, and not all texts succeed in stimulating readers to feel and act as their authors apparently wish" (Keen, 2007, p. 4).

Similarly, regardless of its complex echo within the major events in the novel, Sirine's uncle's storytelling seems to be a kind of a map and instructive for both his audience and the novel's readers. The uncle explains that stories "can point you in the right direction but they can't take you all the way there" (Abu-Jaber, 2003, p. 384).The uncle's storytelling in this case can critically be regarded as a form of allegory for its readers, especially Arabs and Arab Americans; it is conventionally known that storytelling is used to convey a message about real-world issues through hidden meanings and allusions. Storytelling, therefore, as Fadia Faqir argues, is a "form of strong oral Arab culture that reinterprets everyday life" (2011, p. 7). Abu-Jaber, hence, seems to position her storyteller as a figure to build upon, and also to oppose, Benjamin's arguments. The latter claims that "the storyteller is a man who has counsel for his readers. But if today 'having counsel' is beginning to have an old-fashioned ring, 
this is because the communicability of experience is decreasing. In consequence we have no counsel either for ourselves or for others" (1968, p. 86). The opposition between the uncle's storytelling and Benjamin's view can be identified through the increase of communicability between the uncle, as a storyteller, and his audience in the novel such as his niece Sirine who always enquires about some details in the storytelling (Abu-Jaber, 2003, pp. 308-309). Plus, the uncle always provides his audience with consistent counselling. For instance, in one of his conversations with Sirine, the uncle refers to his storytelling as a guidance of "how to love" (Abu-Jaber, 2003, p. 17), given that his niece always fails to open her heart for her lovers. This shows that storytelling is multifunctional: it functions as a source of information, advice, guidance, framework of narratives in the novel, and a medium to project identity.

To shine some light on it, the uncle's storytelling mainly revolves around the moralless story of Abdelrahman Salahadin, an Arab Bedouin slave, who had an incredible addiction to selling himself and faking his drowning only to make money by acting as a guide for unskilled sailors (Abu-Jaber, 2003, p. 17). The uncle introduces him as "the son of a freed Nubian and burdened Iraqi Bedouin" (Abu-Jaber, 2003, p. 54). Abdelrahman was his mother's favourite son (Abu-Jaber, 2003, p. 27) and also the uncle's favourite cousin (Abu-Jaber, 2003, p. 17). The uncle tells Sirine that Camille, the mother of the hero, told him the story of her son when he was a very young boy (AbuJaber, 2003, p. 308). According to Sirine's uncle, Abdelrahman was a pious, devout, and sensitive person who "never forgot to bathe before his prayers. Sometimes he knelt on the beach and made the sand his prayer carpet" (Abu-Jaber, 2003, p. 18). After several unexpected journeys and thrilling events, Abdelrahman eventually ends up a movie star in Hollywood and changes his name to Omar Sharif.

Abdelrahman Salahadin's name, as Sirine's uncle states, is a long name comprised of two meanings: "The Servant of the Merciful One - Abdelrahman - and the name of a great warrior and liberator - Salah al-Din" (Abu-Jaber, 2003, p. 26). Interestingly, his name can critically be regarded as symbolic, or representative, of Islamic identity and history and also Arabness. Names, as Paul Leslie and James Skipper argue, "are not just arbitrary symbols; they signify status, achievement, privilege, and meaningful social organization. They may communicate ethnicity, social status, and social prestige all understood as meaningful within social contexts" (2013, p. 273). For instance, in his 
critique of Andalusian history in Crescent Nouri Gana argues that the name 'Abdelrahman' refers to the Umyyad emir [prince] who escaped the Abbasid massacre of his ruling family in 750 C.E. and fled from Baghdad through North Africa to AlAndalus, which he reached in 755 C.E. A year later, he became the founder and governor of Córdoba” (2008, p. 239). The name 'Salahadin', Gana continues, refers to "the Kurdish Muslim leader Salahadin Al-Ayyubi, who besieged Jerusalem for more than a dozen days before he captured it on October 2, 1187, after 88 years of crusader rule" (2008, p. 239). Interestingly, the composition of Abdelrahman Salahadin's name and its meaning posits a theoretical perspective that it can be related to 'literary onomastics'. Iraida GerusTarnawecky explains that "[n]ames used in literature form an individual, yet, to a certain degree, parallel group to general onomastic material. They are called literary proper names or literary names, and their theoretical study is literary onomastics" (2013, p. 312). Gerus-Tarnawecky further argues that, despite their primary function being stylistic, literary names' individuality “does not prevent a considerable quantity of such names from appearing on both levels in the language system, (e.g. names of historical persons often appear as names of literary characters)" (2013, p. 312). As such, 'Abdelrahman Salahadin' as a meaningful literary name in the uncle's storytelling produces a type of symbolic correspondence to Arab-Islamic history and, to some extent, to mythology as well. Creating such a parallel between the character's name and historically real individuals shows that the uncle is well-educated and a clever storyteller. He not only controls the nature of Abdelrahman Salahadin in his storytelling but also his name.

In the same respect, Abdelrahman Salahadin, the Arab hero in Sirine's uncle's storytelling, can be regarded as a reflection of the co-protagonist Han in the novel in terms of the endeavour to skilfully survive and adapt in a world full of unexpected journeys and traumatic experiences. Given that both of them can be regarded as Middle Eastern displaced figures, the former is situated within a mythical and peculiar world and the latter is located within the context of the USA - in an early twenty-first century socio-cultural realm. In fact, the journey of Han from Iraq to the USA may sound as mythical as Abdelrahman's does. The narrator in Crescent depicts Han's escape from Saddam Hussein's regime in Iraq as adventurous and Hollywoodish: "through the desert into Jordan [...] first in an open Jeep crowded with other refugees, and then on horseback with a group of Bedu, and then finally on foot for two days escaping Saddam's 
guards, mercenaries, Kurdish guerrillas" (Abu-Jaber, 2003, p. 160). The uncle puts both figures - Han and Abdelrahman - in parallel in terms of heroism. He says, referring to Han, "he is like a hero. Like Ulysses" (Abu-Jaber, 2003, p. 18). Furthermore, the stages of displacement that Han goes through are, to a remarkable extent, similar to Abdelrahman's wanderings to understand his destiny and purpose in life. The latter, like Han, undergoes an identity crisis when he reaches Hollywood and becomes a famous actor, holding the name of Omar Sharif:

In his left ear was the soft inhalation and exhalation of the desert and the susurration of the ocean winds. In his right ear was the sharp metallic din of America [...] In his right eye there were parties and girls, directors and scripts, money and fast cars. But in his left eye there was a sort of absence, a nothingness, that he couldn't quite identify. (Abu-Jaber, 2003, pp. 366-367)

The experience of Abdelrahman Salahadin might be seen as a reflection of Han's statement that people of his type - those exiled and displaced - "live in between worlds so they're not really anywhere" (Abu-Jaber, 2003, p. 183). The state of in-betweenness, as seen through Han and Abdelrahman's experiences, is symptomatic of the Arab American diasporic condition and reality. For example, in his research on secondgeneration Palestinian-Americans, Tom Brocket asserts that their life is framed by the sense of in-betweenness. One of his Palestinian-American participants, named Nadia, validates this hypothesis when she expresses her opinion: "when you are in America, you feel like you want to go back - you want to be in Palestine - like you can't relate to everybody, but when you are in Palestine you also can't relate to everybody. So you are stuck in this weird space in-between" (2018, p. 9). The uncle's storytelling and overall plot in Crescent as such are interwoven into each other to strategically mirror the life of Arab Americans as lived in reality.

Equally importantly, the uncle's storytelling projects the Orient as exotic and mysterious, full of adventures as described by early Orientalists, especially "Europeans" (Said, 1995). He can be viewed as a person who is well-acquainted with the geography of the Orient and its civilizations - a Historian. He outlines Orientalist image in his storytelling by recounting exotic adventures in the Orient from an instructive standpoint. This, to a great extent, may reflect Edward Said's definition of Orientalism as an academic tradition as well as "an area of concern defined by travellers, commercial enterprises, government, military expeditions, readers of novels and accounts of exotic 
adventure, natural historians, and pilgrims to whom the Orient is a specific kind of knowledge about specific places, peoples, and civilizations" (1995, p. 203). For instance, the primary setting of the events in the uncle's storytelling is the Arabian Sahara where Abdelrahman Salahadin and his mother Camille encounter mythical creatures in enchanting places, such as genies and mermaids (Abu-Jaber, 2003, pp. 73-74-101-102112). Abdelrahman was abducted by a mermaid who "amuses herself by pretending to be a grieving widow in search of her lost husband and luring innocent Bedouins out to the Ocean and other such places where they have no business being" (Abu-Jaber, 2003, p. 206). This Orientalist portrayal of the Arabian Sahara in Abu-Jaber's novel might be relevant to Graham Huggan's concept of "strategic exoticism" (2001). It refers to "the means by which postcolonial writers/thinkers, working from within exoticist codes of representation, either manage to subvert those codes [...], or succeed in redeploying them for the purpose of uncovering differential relations of power $(2001$, p. 32). In this context, it is possible to argue that Abu-Jaber strategically exoticizes the Arab Sahara to shine a light on some themes that confirm her identity as an Arab American writer - this includes marginality, resistance, and authenticity. By this, Abu-Jaber seems to successfully endorse the cultural and historical differences between the Orient and other parts of the world, particularly the Western one, through the Orientalist agenda in her narrator's storytelling. Such an Orientalist agenda is well apparent through introducing the famous One Thousand and One Nights which is representative of the Orient and accommodative of exotic imaginations that consequently reflect the discourse of Orientalism. Sirine's uncle, for instance, in his storytelling mentions the British explorer Sir Richard Burton who was amongst the first translators of One Thousand and One Nights - its translation pinpoints an introduction of the Orient to the West. Sirine's uncle says: "He had begun his famous, criminal, suggestive, imperial version of Victorian madness dissolved in the sky over the Middle East - his translation of The Thousand and One Nights" (Abu-Jaber, 2003, p. 123). This translation can be regarded as a contribution to the creation of a bridge between two distinct cultures: the imperial and the colonized.

The overall structure of The Thousand and One Nights relies on the tales that Scheherazade recounts to King Shahriyar to save her life and other virgin women from his vengeance. This happens when the king finds out that his wife is unfaithful. He swears to marry different virgin women every night and kill them before dawn. His 
vengeance, however, comes to its end after he marries his vizier's daughter Scheherazade who aims to cleverly change his mind through episodic stories over a course of a thousand and one nights. This collection of interconnected stories was reshaped and retold throughout the medieval Islamic world.

The personification of Scheherazade in Abu-Jaber's novel is apparent through its narrator and storyteller, the uncle, and also through the character of Aunt Camille, the mother of Abdalrahman Salahadin in the uncle's storytelling. This reflects Sabry's statement that "Arab-American women writers and performers revive and re-sound the voice of Scheherazade in myriad tones" (2011, p. 12). For instance, the method that Aunt Camille uses to appeal to the jinn and secure her way to the mother of all fish in her search of her son is similar to the method that Scheherazade uses to save her life from King Shahriyar - the former uses food and the latter uses storytelling. Knowing that the Jinn is hungry, Aunt Camille cooks a delicious dish of eggplant to wittily seduce him to provide her with directions of how to reach the location of her missing son and continue her journey (Abu-Jaber, 2003, pp. 194-195). By this, Diana Abu-Jaber denotes that food is as important as storytelling to the Arab culture. In fact, Aunt Camille can be regarded as a contemporary revival of Scheherazade and a literary device used by AbuJaber to resist, subvert, and correct the reductionist Orientalist views towards women in the Orient, the Arab world particularly, and stereotypical depiction of them as helpless and oppressed. This particular character is a reflection of women figures in The Thousand and One Nights who, as Somaya Sami Sabry argues, "were not helpless victims of their circumstances, but were rather active participants in the unfolding of events around them" (2011, p. 10). In this context, Sabry further argues that storytelling, or Shahrazadian narrative, in Arab American contemporary literature "becomes a narrative of resistance to persistent Orientalist representations which portray these women as silent, oppressed or exotic sexual objects of desire. This resistance is also cultural, since it questions representations of their culture as temporally static" (2011, p. 12). In this context, Abu-Jaber herself comments on the necessity of examining and subverting Orientalist stereotypes. She says: "I push on stereotypes. I will deliberately press on those long-held clichés as a way of testing them" (Field, 2011, p. 211). Both the uncle's storytelling and Aunt Camille's astuteness, as such, refashion the tradition of The Thousand and One Nights. In other words, through these Sheherazadian narratives, Abu- 
Jaber re-appropriates the storytelling's empowered status in Arab culture as well as politicizes its image in the mind of her readers.

In addition, the uncle's implementation of Oriental and exotic elements within his storytelling as well as historical information about the Orient ascribes to him the trait of an "Orientalist translator", as Edward Said puts it. In other words, he positions himself as an agent who introduces the Orient to the West better than Western Orientalists per se because he is equipped with his oriental Arab-Iraqi origin. Even though he is based in the USA, the uncle can critically be regarded on this basis as a typical Orientalist translator who remains outside the Orient and portrays it from a distance - in the US diaspora. In this context, Edward Said states:

The relation between the Orientalist and the Orient was essentially hermeneutical: standing before a distant, barely intelligible civilization or cultural monument, the Orientalist scholar reduced the obscurity by translating, sympathetically portraying, inwardly grasping the hard-to-reach object. Yet the Orientalist remained outside the Orient, which, however much was made to appear intelligible, remained beyond the Occident. (1978, p. 222)

The uncle, in this case, can be seen as reflection of early Arab American writers such as Ameen Rihani and Khalil Gibran whose knowledge of the Orient was remarkable. Their attempt to replace the Orientalist as interpreter or translator of the Orient, as Wail Hassan argues, "was a way of claiming cultural space and voice, countering the negativity associated with the Orient, and mediating between it and the West for the sake of greater cross-cultural understanding" (2013, pp. 43-44). Such cross-cultural understanding in Abu-Jaber's novel is reflected in the connection that occurs between the uncle's storytelling and his audience of different cultural backgrounds.

The process of translating the Orient, and Arab culture in particular, can be supported by the issue of the 'evil eye' in the novel. As is traditionally known, it taints beautiful things and has supernatural and spiritual connotations. It is arguably an old part of the Arab culture and belief related to spirituality and metaphysics. The evil eye, as Arab Bedouins say, "can bring a man to his grave, and a camel to a cooking pot" (AbuRabia, 2005, p.241). It, in fact, has an impact on Diana Abu-Jaber herself. Given that she comes from an Arab family of Bedouin origin, she states that it is something unexplainable: "the evil eye has always been a part of my life, in a way. There is a danger 
in the world that can't always be explained. There's almost a kind of magical element to it; it inserts itself from the cosmos maybe" (Field, 2006, p. 218). The narrator in Crescent refers to this kind of belief when a bird flies into a butcher shop to which Sirine and Aziz go to buy a piece of meat for Um-Nadia. When this happens all the clients rush to leave the shop because they think it is a sign of a 'bad omen' - an evil eye. Odah, the owner of the shop, stressfully comments that "“something or someone -" he eyes Aziz - "has allowed the Evil Eye to enter my shop. Everything is tainted"'” (Abu-Jaber, 2003, p. 170). It also appears in the novel when Aziz, an Arab poet and a teacher of poetry, brings a lamb pie - bought from the same butcher where the evil eye first appeared - to the Thanksgiving celebration (Abu-Jaber, 2003, p.217). And since then, the events in the story escalated into problematic scenes, such as the breakup of the relationship between Han and Sirine, the loss of Han's sister's scarf, and Han's decision to go back to Iraq - where he could be severely persecuted.

Equally important, Diana Abu-Jaber employs the uncle's storytelling as intervals in her novel - an episodic storytelling style by which the uncle continues his stories at the beginning of every chapter. Abu-Jaber makes the readers delve into two different-butrelated stories under one form of literary creation - a novel. Both the uncle's oral storytelling and Crescent's novelistic narratives are complementary and echo each other. This projects a complex union between orality and writing. This hybrid formation may be regarded as a strategy to supplement the reader with various imaginations and dynamic interpretations of the plot and events. This supports the idea that "a hybrid text has spaces within it to be filled in a process of dynamic supplementation and it opens up spaces within the reader" (Hayward, 2015, p. 321). Abu-Jaber mixes the narratives of her novel between the Scheherazadian orality and the Western form of the fictional text - a novel. She transits between the classic narration of oral Arabic tradition and modern Western fiction. She puts herself in parallel with the famous Egyptian writer Naguib Mahfouz whose style, according to Han in his lecture on Arab literature, "is very Western, very accessible to American readers [...] his writing has reflected the social spectrum of his country - he's been part of creating an existing new national identity" (Abu-Jaber, 2003, p. 108). This applies to Diana's attempts to introduce, through her writings, Arab culture and society on the one hand and the lives of Arab American diasporic figures in the USA on the other. 
Diana Abu-Jaber in this regard follows in the steps of the early Arab immigrant intellectuals who conveyed the idea that East and West complete each other. This is apparent in Crescent where the Western form of narrative (novelistic) contributes to the makeup of the Arab tradition of narration (storytelling) and vice versa. She seems to confirm Abraham Rihbany's assertion that "the world needs a characteristic Oriental civilization as it needs a characteristic Occidental civilization" (1922, p. 159). In other words, Abu-Jaber's use of both genres - folkloric and novelistic - can be viewed as, borrowing Wail Hassan's words, a "sort of metaphysical equilibrium and reciprocity: East and West complement, need, and have something to teach each other" (2015, p.45). This process may also evoke what Geoffrey Nash terms 'Anglo-Arab encounter' (2007). Such an encounter is evident through the use of both storytelling as a traditional Arab narration and the Western novel as a modern form of literary production which might signal the intersection of Diana Abu-Jaber's identities. She strategically employs two signifiers of different artistic productions to champion her hybrid form of identity that brings together her Arab-Jordanian roots and American affiliation. This discrepancy between cultures on the basis of artistic productions is further expressed by Han in his conversation with Sirine about her uncle's storytelling. Han asserts that narrating fables and jokes are a means of communication and one of the aspects that differentiates American culture from Iraqi one: "In Iraq, everyone tells jokes and fables. It's too difficult to say anything directly [...] In America, you say 'secret code,' but in Iraq, that's just the way things are" (Abu-Jaber, 2003, p. 52).

The use of the storytelling tradition in Diana Abu-Jaber's novel adds more traits and features to Arab American fiction, or in other words, it changes the outlook of Arab American writers in the contemporary era through recasting such old conventional methods of narration. The significance of this collection of stories, as manifested in the novel by the uncle, can be little more than a footnote or anecdote. It can rather be seen as a map or manner of instruction for both the readers, as explained before, and the characters. In this context, Abu-Jaber comments on the essential purpose behind implementing the tradition of storytelling in her novel:

I wanted it to function as a kind of looking glass for the characters, that would in some way reflect upon the motifs of their reality in an indirect way. I feel that fables have a way of digging deeper; they cut to these verities that are very powerful. For the characters in Crescent, the story of Abdelrahman Salahadin is meant to be a kind of code. If they'd just 
pay attention to the story, it would help them; it gives them a kind of treasure map. (Field, 2006, p. 221)

The art of storytelling furthermore positions Crescent beyond its boundaries and transforms the act of reading, borrowing Madhu Krishnan's words, "from a detached and individualistic mode of communication into a collective encounter with cultural history articulated in the shifting, communal, and multifunctional idiom of orality" (2014, p. 30). For instance, in his Arab literature class that he monitors, Han draws attention to a question: What does it mean to call oneself an 'Egyptian writer' or even a 'Middle Eastern writer' anymore? He continues to explain that "the media is saturated with the imagery of the West. Is it even possible - or desirable - to have an identity apart from this?" (Abu-Jaber, 2003, p. 110). Han's question can be applicable to Diana Abu-Jaber in terms of how she can call herself an Arab American writer, or at least, to be perceived as one. One possible answer to this is that her Arab-Americanness is negotiated through the way she implements the art of storytelling in her novel. Somaya Sami Sabry, for instance, in the context of analysing Arab American women's writing, states that storytelling and orality "are central because they become the means through which our identities and affiliations are framed, defining how we are known and how we know ourselves" (2011, p. 5).

Remarkably, the use of storytelling in this way is not unique or even new - other prominent Arab Anglophone writers such as Fadia Faqir and Rabih Alameddine ${ }^{2}$ implement the art of storytelling in their narratives for many reasons, but mainly to project a hybrid identity of their own. The former, for instance, claims that one of the essential purposes behind writing up her novel Pillars of Salt (1996) was to offer a new vision to English literature, and introduce it as hybrid, by Arabizing it through the insertion of Arabic folkloric tradition of storytelling. In this context, in an interview with Lyndsey Moore, Faqir says:

One of the things I wanted to do with Pillars was to push the narrative and the English as far as possible, to Arabize it [...] to create [...] a hybrid English. Therefore I used the oral tradition and the Qur'an and the Arabian Nights in the storyteller's section. An injection of Arab sensibility, if you like. (2011, p. 7)

\footnotetext{
${ }^{2}$ One of his works that perpetuates the art of storytelling is The Hakawati. Alameddine, R. (2008). The Hakawati. Alfred A. Knopf, Inc.
} 
What Faqir may refer to in this passage is that storytelling is an act of postcolonial resistance and personal cultural triumph. In other words, in employing the Arab tradition of orality in their writings, both Diana Abu-Jaber and Fadia Faqir emphasize their racial origin, cultural affiliation, and ethnic identity - in this case, an Arab. This, in effect, decolonizes their literature.

The practice of orality in a written context, like the case of Crescent, functions systematically to delineate the hybridity of the text which leads to a conclusion that "orality is not merely the antithesis of writing, and that both modes of communication are entwined rather than separate" (Gibert, 2016, p. 2). In other words, Abu-Jaber's novel can be regarded as an example of written orality that sets up a constant dialogue between textual and oral traditions. Such constant dialogue is a type of deliberate narrative technique that has an impact upon the reader in that it promotes more active engagement with the text.

\section{References}

Abu-Jaber, D. (2003). Crescent. W. W. Norton and Company, Inc.

Abu-Rabia, A. (2005). The Evil Eye and Cultural Beliefs among the Bedouin Tribes of the Negev, Middle East. Folklore, 116(3), 241-254. https://doi.org/10.1080/00155870500282677

Benjamin. W. (1968). Illuminations: Essays and Reflections. Trans, Harry Zohn. Schocken Books.

Brocket, T. (2018). From in-betweenness to Positioned Belongings: Second-Generation Palestinian-Americans Negotiate the Tensions of Assimilation and Transnationalism. Ethnic and Racial Studies, 43(16), 1-20. https://doi.org/10.1080/01419870.2018.1544651

Fadda-Conrey, C. (2014). Contemporary Arab-American Literature: Transnational Reconfigurations of Citizenship and Belonging. New York University Press. https://doi.org/10.18574/nyu/9781479826926.001.0001

Field, R. (2006). A Prophet in her Own Town: An Interview with Diana Abu-Jaber. MELUS, 31(4), 207-225. https://doi.org/10.1093/melus/31.4.207

Gana, N. (2008). In Search of Andalusia: Reconfiguring Arabness in Diana Abu-Jaber's Crescent. Comparative Literature Studies, 45(2), 228-246. https://doi.org/10.1353/cls.0.0018

Gerus-Tarnawecky, I. (2013). Literary Onomastics. Names: A Journal of Onomastics, 16(4), 312-324. https://doi.org/10.1179/nam.1968.16.4.312

Hassan, W. (2013). The Rise of the Arab American Novel: Ameen Rihani's The Book of Khalid. In Gana, N. (ed.) The Edinburgh Companion to the Arab Novel in English, (pp. 39-63). Edinburgh University Press. 
Hayward, M. A. (2015). Identity, Transformation and the Anglophone Arab Novel. In N. Gana (ed.), The Edinburgh Companion to the Arab Novel in English, (pp. 321-339). Edinburgh University Press.

Herzog, T. (2012). Orality and the Tradition of Arabic Epic Storytelling. In K. Reichl (Ed.), Medieval Oral Literature, (pp. 627-649). de Gruyter.

Huggan, G. (2001). The Postcolonial Exotic: Marketing the Margins. Routledge.

Irwin, M., \& Auster, P. (2013). Memory's Escape - Inventing the Music of Chance: An Interview with Paul Auster. In J. Hutchisson (Ed.), Conversation with Paul Auster, (pp. 40-49). University Press of Mississippi.

Keen, S. (2007). Empathy and the Novel. Oxford University Press. https://doi.org/10.1093/acprof:oso/9780195175769.001.0001

Krishnan, M. (2014). The Storyteller Function in Contemporary Nigerian Narrative. The Journal of Commonwealth Literature, 49(1), 29-45.

https://doi.org/10.1177/0021989413510519

Masalha, N. (2018). Decolonizing Methodology, Reclaiming Memory: Palestinian Oral Histories and Memories of the Nakba. In N. Abdo, N. Masalha (Eds.). An Oral History of the Palestinian Nakba, (pp. 6-40). Zed Books.

Michael, M. C. (2011). Arabian Nights in America: Hybrid Form and Identity in Diana Abu-Jaber's Crescent. Critique: Studies in Contemporary Fiction, 52(3), 313-331. https://doi.org/10.1080/00111610903379958

Matravers, D. (2014). Fiction and Narrative. Oxford University Press. https://doi.org/10.1093/acprof:oso/9780199647019.001.0001

Moore, L. (2011). You Arrive at a Truth, Not the Truth: An Interview with Fadia Faqir. Postcolonial Text, 6(2), 1-13.

Nash, G. (2007). The Anglo-Arab Encounter: Fiction and Autobiography by Arab Writers in English. Peter Lang. https://doi.org/10.3726/978-3-0353-0419-0

Rihbany, A. (1922). Wise Men from the East and from the West. Houghton Mifflin.

Sabry, S. S. (2011). Arab-American Women's Writing and Performance: Orientalism, Race and the Idea of the Arabian Nights. I.B. Tauris.

https://doi.org/10.5040/9780755616718

Sabry, T. (2010). Cultural Encounters in the Arab World: On Media, the Modern and the Everyday. I.B Tauris. https://doi.org/10.5040/9780755610884

Said, E. (1978). Orientalism. Penguin Books.

Serrat, O. (2008, October 10). Storytelling. Knowledge Solutions. https://www.adb.org/sites/default/files/publication/27637/storytelling.pdf

Skipper, J. K., Leslie, P. L. (2013). Toward a Theory of Nicknames: A Case for Socioonomastics. Names: A Journal of Onomastics, 38(4), 273-282.

https://doi.org/10.1179/nam.1990.38.4.273 